\title{
Masculinities, Femininities and Work - The Horizontal Gender Segregation in the Danish Labour Market
}

\author{
I Lotte Bloksgaard \\ Assistant professor, FREIA Gender Research Center, Aalborg University, Denmark
}

\begin{abstract}
Most job functions, tasks and professions are gendered as either 'masculine' or 'feminine'. On the basis of two empirical studies of women in 'men's jobs' and men in 'women's jobs' the article shows how societal ideas about and relations between gender and work affect the way in which individual women and men develop their identities and hereby influence women's and men's work orientations and working life. Thus, the article provides a greater understanding of the gendering processes which contribute to the creation of gender segregation in the Danish labour market.
\end{abstract}

\section{KEY WORDS}

Gender segregation / division of labour / gender identity / masculinity / femininity / gendered jobs.

\begin{abstract}
he Danish labour market is highly gender-segregated ${ }^{1}$; it appears as one of the most gender-segregated labour markets in the EU (Emerek \& Holt 2008; 28). This is mainly due to the horizontal segregation, i.e. the fact that women and men are employed in different sectors and professional fields and with different tasks. But how can we explain the continuing reproduction of this segregation? Why do men become craftsmen and IT experts, while women become nurses, secretaries and educators? These issues are the main theme of this article. The purpose of the article is to shed light on the way in which societal and cultural constructions of and relations between gender and tasks/professional fields are affecting the thoughts and actions of individual women and men in work life. And thus to obtain a deeper understanding of how the gender division is continuously being created through women's and men's development of gendered identities in relation to work.

The first paragraph outlines a number of figures and central concepts regarding the gender-segregated Danish labour market, with a special focus on the horizontal segregation. The next section presents a theoretical view that explains the horizontal segregation in relation to constructions of and relationships between jobs, gender and identity. On the basis of two empirical studies of women in 'men's jobs' and men in 'women's jobs' the remaining part of the article illustrates and discusses how societal conceptions about gender and work influence women's and men's development of identity in relation to work and working life in four gendered professions.
\end{abstract}

Lotte Bloksgaard, : Department of Culture and Global Studies, Fibigerstraede 2, room 85, 9220

Aalborg East, Denmark. E-mail: bloksgaard@cgs.aau.dk 


\section{The gender-segregated Danish labour market}

Significant changes have occurred in the Danish labour market during the last 40-50 years - for instance there has been a dramatic increase in women's participation and involvement in the labour market. Danish women's participation is among the highest in the world; thus, today women constitute $47 \%$ of all employees in Denmark (Emerek \& Holt 2008; 28). Although today Danish women participate in the labour market almost as much as men, they are working in other parts of the labour market, with other tasks and in other job functions. Thus, at the beginning of the new millennium, the Danish labour market is still highly gender-segregated (Holt et al. 2006 Emerek \& Holt 2008).

The gender segregation in the labour market has both a horizontal and a vertical aspect. Horizontal segregation refers to a systematic distribution of women and men in different sectors, different professional fields and different job functions, even within the same workplace and profession (Dahlerup 1989: 14). The term thus refers to the fact that the labour market is to a great extent divided into "jobs for women" and "jobs for men" - that certain professions are particularly dominated by and associated with one sex - for example fireman, craftsman ('male jobs') or midwife, nurse ('female jobs'). These jobs are also called 'one-gendered' jobs (Dahlerup 1989). A distinctive feature of the gender division is the fact that often a higher status and more prestige will be attached to what men are doing (Dahlerup 1989, Kold 1997), which is also reflected in the fact that 'male jobs' are often better paid than 'female jobs' (Warming 2007, Udsen, 2008). Vertical segregation refers to segregation within the hierarchy of the labour market and specific workplaces (Dahlerup $1989 ; 14)$; i.e. the fact that women will typically rank lower in the hierarchy concerning pay, opportunities for promotion, mobility and chances to enhance qualifications in their jobs than men. For instance, many types of 'women's jobs' have traditionally been 'assistance' to men's jobs; secretaries as assistants to the executives, nurses as assistants to doctors, etc. In addition, vertical gender segregation is often integrated in the horizontal gender segregation. In many cases, the horizontal segregation is tilting upwards at the men's side, because more often than women, men are employed in industries, professional fields and job functions from which there is upward mobility and opportunities for further qualification. Even with the same education and in the same workplace, men are typically being assigned the work tasks with the most prestige. This phenomenon is called 'sliding gender segregation' in the workplace (Dahlerup 1989, Holt et al., 2006, Bloksgaard 2009a).

Although the latest analyses of the development of the gender segregation in the Danish labour market show that in several ways this is changing, there still seems to be a general trend towards strong occupational gender segregation. This is mainly due to the horizontal segregation. While movement has been recorded in the vertical segregation in the Danish labour market - today women more often become leaders - the horizontal segregation has remained largely unchanged over the last 10 years (Holt et al., 2006 Emerek $\&$ Holt 2008). Women are over-represented in the regions and municipalities, while men are over-represented within the State and the private sector $-80 \%$ of all men are employed in the private sector, while $40 \%$ of all women are employed in the regional/municipal sector. Women are primarily employed in occupations that are characterised by clerical work and care, while men are employed in the craft sector (Holt et al. 2006: 11). To describe the degree of segregation in a particular discipline, the following terms are useful: 'highly gender-dominated professions" (one sex accounts for $80 \%$ or more of the workforce), 'gender-dominated professions' (one sex accounts for 20-39\% ) and 'gender-mixed' professions (one sex accounts for 40-60\%) (Emerek \& Holt 2008). Emerek and Holt show 
that the shares of both women and men employed in gender-mixed professions are about $5 \%$ higher in 2007 than in 1997. The main tendency is still clear, however: Only a quarter of the men and nearly one-third of the women in the Danish labour force worked in gender-mixed professions in 2007 (Emerek \& Holt 2008; 40). Thus, there must still be said to be 'work for men' and 'work for women' in the Danish labour market.

\section{Constructions of job, gender and identity}

The gender segregation of the Danish labour market has long historical roots, but is not only a token of a historical backlog; it is also being actively created in processes today. Among other things, it may be understood as something which is being created as part of individual women's and men's development of identity in relation to work. Within gender research the social constructivist perspective has been gaining acceptance over a number of years. Concurrently, there has been a tendency to move away from seeing gender as something essentialistic, i.e. as something one 'is'. Instead, gender is understood as something that is continuously being 'done' or negotiated in relations between people (West \& Zimmerman 1987, Kvande 1995, Christensen 2001). Based on such an understanding, gender becomes something complex and changeable; women and men can develop one gender identity of several possible - it becomes relevant to talk about several masculinities and femininities (cf. e.g. Connell 1995, Christensen \& Larsen 2003). So, according to this perspective, you can be a man or a woman in several different ways; but at the same time it is a central thought that women and men develop their masculine or feminine identities in relation to cultural ideas and ideals about gender - i.e. the conceptions which exist at any time on what 'masculinity' and 'femininity' "are". For example, men are typically considered to be rational, powerful and physically strong, while women are considered to be emotional, caring, and physically weak. The images constructed of women and men, respectively, are built on a dichotomy, i.e. they are reciprocally exclusive. In addition, male qualities are often assessed higher than feminine qualities (Hirdman 1988, 1990, Connell 1995, Kvande 1995). In continuation of these cultural ideas about gender, there are very specific frameworks as to how we - as women or men - can act if we want to be perceived as meaningful in society. This is because certain forms of behaviour are seen as 'appropriate' or 'inappropriate' depending on whether you are a woman or man (West \& Zimmerman 1987).

In the labour market, the notions of women's and men's qualities are being related to certain tasks and professions. Thus, most work tasks and jobs are gendered as either 'feminine' or 'masculine' and are therefore seen as especially suited for either men or women. Examples of jobs which are strongly gendered as masculine are fireman and policeman, while secretaries, educators and nurses are generally associated with various forms of femininity. The gendering is not given in advance; it is a social construction - almost any job can be characterised as either masculine or feminine by highlighting certain dimensions and by labelling these in a certain way (Alvesson \& Billing 1999; 103). That the gender division is a social construction can be seen from the fact that it changes over time or varies in different societies and cultures. An example is the electricity profession which in Denmark is a highly gender-dominated male profession, while it in Romania is a gender-mixed profession (Bloksgaard 2009c). But when, in the labour market, we meet men as carpenters, police officers and executives and women as nurses, pedagogues and secretaries, the notion that the two sexes have different qualities and competences is 
recreated and enhanced. And, in continuation of this, norms about what is appropriate work for women and men respectively are established.

\section{Gender-(un)conventional job choices}

The construction of jobs, professions and tasks in terms of masculinity and femininity has a great impact on the way in which men and women are placed in the labour market and in organizations. Gender is something we as individuals think and do, for example in work life organizations, where symbols and ideas will, to a large extent, inform women and men about how they should live their (working) lives (Acker 1991, Gherardi 1994, Kvande 1995). Men and women identify with, orientate themselves towards and find it natural to act upon the cultural conceptions of masculinity, femininity and work - or at least, in most cases, they do not directly break with these. When we choose education and work, our choices are therefore to a large extent made on the basis of what is meaningful in relation to our self-image and gender identity. Gender divisions help to strengthen the individual's gender identity, since they confirm our conceptions of what a 'real man' and a 'real woman' are. And because the gender divisions help us to define this, both men and women may have a desire to maintain such divisions in the labour market.

Therefore, people who break with the established conceptions about appropriate and non-appropriate tasks for women and men may constitute a challenge both to their own sex and the other. Firstly, such 'gender pattern breakers' will often be met with scepticism from their surroundings. Secondly, the individual woman and man who follows roads which are still seen as atypical for his/her sex, will be troubled by uncertainty in relation to whether they are sufficiently masculine or feminine. An important thing for men is, for example, to show signs of masculinity and avoid dealing too much with tasks that are seen as feminine - so, differentiating themselves from women is crucial in the development of masculinity (Williams 1991, Alvesson \& Billing 1999).

\section{Women in 'men's jobs' and men in 'women's jobs'}

The following sections are based on two empirical studies: a comparative study among male nurses and female police officers (Bloksgaard \& Faber 2004), and a study of men in the social and health care profession and women in the electricity profession (Bloksgaard 2009b, 2009c).

Men represent about $3.5 \%$ of the total number of nurses ${ }^{2}$ and just under $5 \%$ of employees in the social and health care profession ${ }^{3}$ in Denmark. Women represent about $12 \%$ of the total Danish police force and less than $1 \%$ of members of the Danish Union of Electricians ${ }^{4}$. Nursing, the social and health care profession, the police force and the electricity profession are all examples of highly gender-dominated professions. In addition to this, all of these are also what might be called 'especially gendered professions': The image of the traditional nurse or of the social and health care employee is synonymous with femininity: care and motherliness. In the same way as the images of police officer and electrician are synonymous with masculinity: authority, power and physical strength and craftsmanship, physical strength and technical skills, respectively. These pro- 
fessions can therefore be regarded as particularly suitable for examining the mechanisms that maintain the gendered structures in the gender-segregated Danish labour market ${ }^{5}$.

The study Gender at Work. A qualitative study of male nurses' and female police officers' working life (Bloksgaard \& Faber 2004) is based on interviews with a number of male nurses and female police officers. The study Male social and health care employees and female electricians - why not? (Bloksgaard 2009b) is based on interviews with upcoming, current and former male social and health care employees and female electricians. And on interviews with a number of potential male social and health care employees and potential female electricians - these are included in order to illuminate barriers to and motivators for going into these professions among the 'unconventional' sex. It is on the stories of these women and men that the analyses in the following section are based.

\section{A job for the opposite sex?}

The two studies show that all four professional fields are gendered, i.e. constructed and perceived as either masculine or feminine. This may probably prevent members of the 'non-traditional' sex from orienting themselves towards and choosing the professions. That the gendering of the profession may be an essential explanation of the female dominance in the social and health care profession, is particularly evident from the interviews with the prospective male social and health care employees. These men were recruited at an information meeting in connection with the course 'Real men wanted for work that makes sense' for unemployed people ${ }^{6}-$ the course provides a tryout of three different types of job: home carer, social educator and hospital porter. I ask the men which of the three jobs they are interested in - Erik answers:

Erik: Mainly hospital porter. Or perhaps also social educator.

Int.: So you see yourself best in these jobs? Not in home care?

Erik: It might be when you got to know it. I won't rule it completely out... But it is not the jobs I've inclined most to earlier or know best....

Int.: Why do you think that is the job that will appeal least to you?

Erik: Well, I don't know... I like going out and talking to people and I also have some elderly people in the company I keep and where I live. But as I said, I don't know.? (laughs) To be quite honest; the other jobs may be more male jobs maybe...?

Int. What is it about the home care that doesn't appeal to you?

Erik: Well, there's not really anything that speaks against it, I think..? But I guess one hasn't thought about moving that way right? I'll have to admit that I haven't earlier (laughs). (Erik, potential social and health care employee) (Bloksgaard 2009c)

This and similar statements show that many of the unemployed men who are considering to attend the course are aiming at the training to become hospital porter or social educator whereas they indicate that home care does not appeal to them to the same extent. This in spite of the fact that many of the men are motivated to work with people, and it is difficult for them to identify concrete aspects of home care that do not appeal to them. The interview material suggests that men's de-selection of home care as a job happens automatically; due to a perception that to work here 'is not what men do', they do not even consider this job as relevant. 
Several of the men employed in the social and health care profession and in nursing state that the job content - or what the surroundings believe is the job content - is perceived as 'women's work'. This idea is connected to the societal belief that women and men are born with different biological predispositions, and that for example women are born with a special ability to provide care. In continuation of this, a perception that care is not work for a man is created. Leif, former social and health care employee, explains:

"This job is taboo-breaking for many men: an older person whose private parts we need to wash, for instance. There are plenty of men in the ambulance service, and they also experience things that other people cannot cope with, but that is blood and so on. I think it is very much part of our upbringing, that women care for both girls and boys. You may think, what you want about that, but it is more natural that a woman washes women and men, than for a man to do so!" (Leif, former social and health care employee) (Bloksgaard 2009c)

While the tasks of the ambulance service, which involves contact with blood, may be performed by a man, care is clearly associated with women. Men who are employed with this task or consider the job may therefore meet scepticism. Keld, social and health care employee, explains about reactions from his surroundings:

"They find it hard to swallow. 'Can men really do that??' They get a bit surprised. And a bit shy too, because they know that you are in close contact with the patient. It's not a male job. It's a soft job... A lot of my family and friends were surprise, when I chose it. They still think it's a job for women and are surprised that a man can do the job and be so intimate with other human beings in a job. My parents are still having trouble understanding it. They are saying: 'Are you giving ladies a bath then??!'” (Keld, social and health care employee) (Bloksgaard 2009c)

Such reactions from the surroundings are instrumental to gendering the social and health care profession and nursing even more as feminine and may discourage men from seeking employment in these professions.

The two studies show that electricity jobs and the police are, in contrast, constructed as jobs gendered as masculine. Several of the potential female electricians state that they have experienced that people in their surroundings are questioning whether it is a job for a woman. Julie explains:

"People take for granted that it is a job for boys. Only men apply. You are being labelled rather quickly. 'You won't be able to do that!' A lot of people react that way: 'Do you want to be an electrician? You won't be able to perform that job. You'll have to be a man to do that!'” (Julie, potential electrician) (Bloksgaard 2009c)

Julie's story illustrates that there is a clear understanding that the electricity profession is 'men's work'; that the job tasks require 'male' qualities. The job has an image as a physically hard job, and therefore it is 'naturally' associated with masculinity. Kristine says: " $I$ believe that there are many who still think that you must be big and strong to be a craftsman. Only real men can be that." (Kristine, potential electrician) (Bloksgaard 2009c). Also with regard to content - to work with one's hands - and that you may become dirty 
is perceived as contrary to the feminine - Julie explains: "I also believe that man people think so, because they think that we are very 'delicate' girls. Many of our friends have said: 'Are you two not a bit too delicate to be in that job? You may break a fingernail!!'” (Julie, potential electrician) (Bloksgaard 2009c). The two young women both have long artificial nails, wear make up, jewellery and have long hair, and such obvious signs of femininity are apparently not consistent with the image of professionalism in manual jobs, where you may get dirty and "break a nail" (see also below).

The interviews with the female police officers clearly show that also the police force is a profession gendered as masculine. The police force is associated with qualities such as physical strength and authority. The surroundings therefore find it difficult to come to terms with the image of a woman in the role of police officer. Mia explains that from her surroundings she encounters an expectation that she - since she is a police officer must be a "special" woman; an exception to the female sex in general: "Sometimes they almost expect that I must be an expert on karate, since I can be a woman and a police officer." (Mia, police officer) (Bloksgaard \& Faber 2004). According to Mia, it is difficult for people to understand that she is an ordinary woman and at the same time a police officer - and if a woman is so competent that she can be a police officer, she must be a kind of "superwoman" and not a normal woman!

The female police officers also find it difficult to appear as persons of authority. Several of the persons interviewed state that some citizens are questioning women's skills in the job: "Two female police officers on patrol are risking much more trouble because some people like to put us to the test because we are women. So you have to stand up for yourself much more to get respect" (Birgit, police officer) (Bloksgaard \& Faber 2004). Other female police officers express that (stereotypes about) their sex may be an advantage as it can dampen violent situations, as (some) men refrain from hitting a woman. For the female electricians, it is not part of the job's core function to appear with authority. A few of the female electricians express, however, that they feel that trainees or colleagues find it hard to accept instructions from a woman: "I was to manage some of the work gangs, and they had difficulties accepting that I was the one to give them instructions (...) something like 'a girl should not appear to know more than me...' Some men cannot accept that at all.” (Linea, 29 years, former electrician) (Bloksgaard 2009c). Apparently there are some issues at stake about gender, power and authority.

Mia's quote above actualises an important result in both studies: that there is a pronounced difference in how the surroundings - when they have got over the initial surprise - look at women and men who undertake work tasks which are perceived as appropriate for the opposite sex: the female electricians and police officers state that they are mostly met by admiration and acclaim for being able to handle 'men's jobs' for example Ditte, who is a police officer, states that she "has received only positive response. Most think it's a bit impressive" (Ditte, police officer) (Bloksgaard \& Faber 2004). The male nurses and social and health care employees are receiving more negative reactions to their unconventional career choices. Wilhelm, nurse, explains for example:

"My friends had so much fun about the fact that I had to 'wipe ass' and stuff like that. They had some kind of negative attitude: 'you cannot do such things!'. There have been a lot of reactions like that: 'A man cannot be a nurse!'” (William, nurse) (Bloksgaard \& Faber 2004) 
A job task like for example washing patients is by many - especially other men - seen as unimaginable as a task to be carried out by a man; it is difficult for many people to understand that a man is (voluntarily!) undertaking 'female' work tasks. Especially the female dominated care professions are characterised by having a low status. But while it seems to be accepted that women undertake such jobs - they are filling a traditional female position, after all - people are wondering why men choose to apply for such jobs, as they break with the traditional image of masculinity. The difference in attitude towards women and men who undertake 'the work tasks of the other sex' shows that women are, to a lesser extent than men, looked down upon when they undertake 'the work tasks of the other sex': 'men's work' is in general valued higher than 'women's work' (Kold 1997).

\section{Gendered qualities and job division}

The interviewed gender minorities from the four professions have all received the same training and have the same qualifications as the majority of employees within the respective professions. Nonetheless, there is a tendency that women and men are employed in different fields of work (formal gender division of labour) or that in their daily work they are assigned and /or undertake different qualifications and work tasks based on stereotypical conceptions of gender (informal gender division of labour).

It is characteristic that men in 'women's jobs' typically orientate towards and engage in specific domains or specializations (Williams 1991, 1995, Nielsen 2003, Simpson 2004, Warming 2005, Sjørup 2006). This trend is also seen among the male nurses and social and health care employees in the two studies - these are extensively engaged in or apply for jobs in areas such as emergency wards or the area of psychiatry, which have traditionally been areas in which men have been employed ${ }^{7}$. The trend that men are drawn to these specific areas is partly due to the fact that these are gendered as more masculine, and that these have more men employed - both are important factors regarding men's maintenance of masculine identity (elaborated below). As described above, men in 'women's jobs' are often met with scepticism and are denigrated because they break with the traditional image of masculinity - the image of what is 'appropriate' work for a man. The fact that men are attracted to special 'man positions' can thus be understood as a part of legitimizing that they, being men, choose employment in 'female jobs' (Williams 1991, 1995, see also Bloksgaard \& Faber 2004, Warming 2005). From the accounts of the female police officers and electricians it is not equally obvious that there is a formal gender division of labour in the police force and in the electricity profession, i.e. that women are attracted to specific work domains or specializations. A possible explanation might be that, due to the scepticism they face here, some women in 'men's jobs' insist on not wanting to undertake 'special work tasks for women' in the professions (Bloksgaard \& Faber 2004, Bloksgaard 2009c).

If we take a closer look at the more informal gender division of labour in the daily work in the professions, the two studies suggest that this takes place especially in nursing and the police force. The majority of the male nurses explain that they feel that there are tasks which are regarded as particularly 'male' and that they are therefore sent for to perform tasks that "require a man", for instance heavy lifting, repair of technical equipment, dealing with violent or recalcitrant patients, etc. Nicolai, nurse, says: 
"If something needs to be fixed: 'Can't you fix it Nicolai?' I'm not very good with machines, when we get new machines, I'm actually late to get to know them. I'm more interested in people and not so much in mechanics. But if a machine is not working at our department, they always shout: 'Nicolai, please come and take a look at it and find out what's wrong?' But Nicolai doesn't always know what to do!" (Nicolai, nurse) (Bloksgaard \& Faber 2004)

Nicolai's story shows that the social construction which is 'naturally' linking all men to the qualities which are considered masculine is problematic, and that what we understand as femininity, may also be 'done' by men (see also Nordberg 2004 for a discussion of 'male femininity' and 'female masculinity'). The interview material illustrates that also respect and authority are qualities associated with the male sex. Again it is Nicolai, who explains how he feels that the construction of such qualities as masculine impacts on the division of labour in nursing:

"Many people think that when you're a man, you are most likely in charge of the ward. And if I say 'this is Karen the charge nurse or Bodil the assistant charge nurse, then they kindly shake hands with them but keep on talking to and looking at me! And the girls - my colleagues - do the same thing. And the doctors too. A lot of times it makes me feel uncomfortable. Just as recently as today, when our chief physician did his rounds, he came up to me and said, 'What about this Nicolai - how is it with this?' So I said 'You'll have to ask the charge nurse, because I don't know anything about it!'” (Nicolai, nurse) (Bloksgaard \& Faber 2004)

As the quote illustrates, the men do not necessarily experience it as beneficial to be assigned special authority. Situations like the above may create ambivalence in the male nurse as he gets confronted with the fact that he does not live up to the expectations attached to the male sex. At the same time, the existing gender mechanisms may have a negative impact on the day-to-day working relationships, for example with their female superiors.

Also some of the female police officers feel that the distribution of tasks may be affected by gender - women are often left with the more socially oriented tasks, which include contact with women and children. Some of the women explain that they have experienced "officers in charge who think they must look after us, so if there are some violent tasks they will not send us out" (Kirsten, police officer) (Bloksgaard \& Faber 2004). Women will always be in doubt whether these kinds of considerations are made on the basis of respect for their femininity (as previously described, femininity is associated with lack of physical strength), or because the man is doubting whether the woman is competent for the task (Bloksgaard \& Faber 2004).

Employees in the social and health care profession (particularly home care) and the electricity profession often work on their own, for example in the homes of citizens/customers. This organization of work entails that all employees must be able to perform all work tasks and probably counteracts a gender division of labour on a daily basis in these professions. Some of the interview stories do, however, show examples of women and men being ascribed different qualities and work tasks. Female electricians are constructed as more careful, tidy and deft with their fingers than men - and consequently, some of the women are given/undertake a larger number of "fiddly tasks". The male social and health 
care employees experience being ascribed qualities such as technical skills and craftsman skills - and are given/undertake a number of craftsman tasks, while their female colleagues are performing the traditional house(wife)tasks, e.g. cleaning (Bloksgaard 2009c, see also Krøjer 2003). Ibrahim, social and health care employee, said:

"I like to vacuum, but I hate dusting, and then there's some of my colleagues who like it and take care of it. Then I can do the things they cannot, for example fix a roller blind that is stuck or a wheelchair which is missing a screw or a ... Sometimes I do things for our janitor. I repaired a toilet that couldn't flush, so there may be a handyman hidden in me. Nobody is exploiting it, it's more like: 'could you please do this...?'” (Ibrahim, social and health care employee) (Bloksgaard 2009c)

As the quote shows, the division of labour "is not something that is being exploited" but something that happens 'naturally' - based on expectations about the different qualities and skills as something innate in the two sexes. Gherardi calls this phenomenon - that both women and men, more or less consciously, undertake tasks in work life which are associated with their sex and thus 'keep their places' - 'repair work', carried out in order to normalize the gender order (Gherardi 1994).

This section shows that even when women and men have the same education and are employed to perform the same tasks, a gender division of labour based on notions of appropriate behaviour of the two sexes frequently takes place in day-to-day work at the workplaces. As described, such sliding gender segregation often results in men ending up in positions with better pay and more opportunities than women (Williams 1991, 1995, Holt et al. 2006).

\section{Ambivalence, identity work and gender strategies}

As described above, people seeking employment in professions dominated by the other sex and labelled as 'appropriate for the other sex', are often met by surprise and scepticism. People are especially uncomprehending to the fact that men will voluntarily undertake female tasks. This leads to the idea that men who choose such a 'feminine' job must necessarily be very feminine men - and from this follows a widespread belief that male nurses and social and health care employees are gay. Michael, who is a potential social and health care employee, and has earlier interrupted an education to become a nurse, says: "I remember the first comments, when I started: 'What the hell? Have you become gay?' You get a lot of comments like that. About it not being very masculine". (Michael, potential social and health care employee) (Bloksgaard 2009c). And Tobias says about being male and being employed in a social and health care job: "Well, it has always been said that it is a jobfor women, and if a man got employed there, he's either gay or strange. I've heard that a lot. From friends and such ... But they think it is cool that I have the guts to do it" (Tobias, training to be a social and health care worker) (Bloksgaard 2009c). In the interview Tobias appears as gender-conscious; he expresses a desire to change the gender segregation in the Danish labour market: "It would suit me just fine to help breaking the myth that it is a job for women only. Men can do it just as well as women" (Tobias, training to be a social and health care worker) (Bloksgaard 2009c). Apparently it suits Tobias fine to be a pattern breaker and to go against the 
traditional image of masculinity and work. At the same time, his initial statement points to the fact that such a view/such a gender-policy perspective is not widespread in Danish society and that a man (therefore) needs to have courage to go against the dominating image of masculinity.

And indeed, very few of the interviewed male social and health care employees and nurses respond/react like Tobias. Generally the men express a fear of appearing as, and of being judged as, unmanly because of their unconventional choice of employment: " $I$ thought a lot about the risk of being considered as feminine. Cause I'm not at all feminine! I thought a lot about how my surroundings would look at me - would they consider me as such a femme guy? I was very worried about that..." (Nicolai, nurse) (Bloksgaard \& Faber 2004). Prejudices about homosexuality in men working in 'women's jobs' generally cause great ambivalence and identity work, see below, among the men interviewed. The interviews show, however, that also the men themselves are reproducing this stereotype. Kristian, nurse, explains that he has agreed to be interviewed

"... to show that male nurses are also very ordinary men with ordinary, healthy, male interests. I probably felt that I had to stand up for a second type of male nurse (...) I'm probably a little more of a jumping jack than such people usually are. I'm not such a sissy gay!” (Kristian, nurse) (Bloksgaard \& Faber 2004)

This statement shows clearly that we are all under the influence - and all co-producers of the social constructions of gender and work.

Because to a great extent, the men feel that their surroundings are questioning their masculinity, they are seeking actively in their work lives to signal that they are "real" men - one might even say that they are exhibiting a kind of 'hyper-masculinity' (Bloksgaard \& Faber 2004). This manifests itself in them moving towards masculine domains and specializations in their professions, and also in them emphasizing masculine aspects of their work and possibly dissociating themselves from the core tasks. Moreover, the men are seeking to avoid company with the women in their professions - instead they seek the company of other men in the professions with whom they can engage in 'male communities' (see also Svare 2009). The men are using all the outlined strategies to maintain a positive masculinity in the eyes of others and at the same time a masculine self-image despite the fact that they are working in a 'women's job’ (Bloksgaard \& Faber 2004, Bloksgaard 2009c, see also Williams 1995, Nielsen 2003, Warming 2005, Sjørup 2006).

The two studies suggest that the stereotype about homosexuality does not exist to the same extent as regards women in 'men's jobs' - only a few of the women say that they have met this prejudice in their working lives. Yet the interviews with the female police officers and electricians show that also women in 'men's jobs' are continuously engaged in comprehensive identity work. Women doing 'men's jobs' are often put to the test and must prove their worth before they are accepted on equal terms with the men in the same professional field. A familiar 'strategy of survival' among women in male jobs is to downplay gender differences and seek to become 'one of the boys' to live up to the male norm - both professionally and socially - in the professions (Bloksgaard \& Faber 2004, Bloksgaard 2009c, see also Kanter 1977, Martin 1980, Finstad 2005). Also with regard to appearance, some of the women, particularly the female police officers, are trying to downplay their femininity. For example, Mona has long hair, but she says she 
never wears it hanging loose at work - both because it is impractical, but also because she does not think that loose hanging hair matches the role of a police officer:

"I would never wear my hair hanging loose at work. I don't think it goes with the uniform... I don't know whether it's because it looks untidy, but it sends a signal. I wear my hear hanging loose in my spare time, so it is something I'm conscious of, to look decent. I don't think it looks right standing there in a uniform, supposed to radiate authority, and then have your long hair with hairspray in it hanging loose... Here at the secretariat I could have it hanging but it is so deeply ingrained in me..” (Mona, police officer) (Bloksgaard \& Faber 2004)

Several of the female police officers have a feeling that the symbols of femininity - long hair or a skirt - are inappropriate in situations where they must appear with authority. It is difficult for them to explain exactly what this feeling is based on, but as a result of this they have a feeling that they must hide their femininity at work, i.e. appear to be gender neutral. So the women experience that overt femininity tends to be associated with non-professionalism in the police force and that therefore they are most likely to be accepted as professional equals if they make an effort to imitate the men. The women's 'playing down' of their femininity can be seen as a need to downplay their sexual attractiveness in a male-dominated profession, as several of both the female police officers and electricians find that their sexuality can cause problems for them in their working lives (Bloksgaard \& Faber 2004, Bloksgaard 2009c).

It is a common experience among the women in the two professions that they feel that everyday life among many men and their own attempts to become 'one of the guys' are influencing them, even outside the workplace - the masculinisation that characterizes their work lives is also changing them as individuals. Linea, a former electrician, says:

"You adapt a terrible language. Craftsman jargon. But you don't think about it. Suddenly you have to make an effort to think about it outside work, to talk nicely as a girl ought to talk.” (Linea, former electrician) (Bloksgaard 2009c)

Several of the female officers and electricians state, like Linea, that they themselves are aware that they are taking over the men's jargon and that they are making an effort to maintain a decent language, and thus live up to expectations of how "a girl ought to talk". The use of uniform in both the police force and in the electricity profession contributes to the masculinisation which the women are experiencing at work - for example Berit, who is a police officer, says: "This uniform - it's not particularly feminine. I always wore a skirt when I worked as a police officer at the airport. And it was nice, I thought, because you didn't feel so masculine.” (Berit, police officer) (Bloksgaard 2009c).

The stories of the women show, however, that generally they have to be careful not to become too masculine in their working lives, as they experience that it is not acceptable if a woman acts too much like a man. Linda, police officer, says:

"I think that as a women you receive more respect if you are yourself. I'm not one of the guys, although I can do the same things as the guys! I can see that sometimes if I'm saying something coarse, then my male colleagues are almost bowled over, because they think I'm too rough - then they actually become a bit offended." (Linda, police officer) (Bloksgaard \& Faber 2004) 
This and some of the other women's stories suggest that if women in 'men's jobs' become too much 'one of the boys', they overstep an invisible boundary between the two sexes; a boundary that defines what is permissible for women and men respectively. And as described, women and men who do not live up to the ideas of appropriate gender behaviour, are to a great extent met with scepticism.

The interviews show that many of the women are also themselves experiencing ambivalence about the masculinisation they experience at work - several emphasise that it is important for them to continue to appear feminine:

"You look like a man all week-days. You don't feel very pretty when you are leaving home in the morning. I wouldn't go out shopping in those clothes; I'd go home and change first. I'm not walking around in my working clothes. I often think that the other girls in the electricity profession look more male and dress like men, but I think it's important to look like a girl. It's important for me to show that I'm still a girl (...) Some don't think that you are a girl-girl. Some are wondering 'if you're a real girl? "But I am!". (Sofie, electrician apprentice) (Bloksgaard 2009c)

Stories from the female police officers and electricians show that many of the women feel a certain perplexity in relation to their gender identity, being employed in 'men's jobs'. However, the women's identity work differs in several ways from the identity work performed by men in nursing and the social and health care profession. While the men are actively seeking to signal masculinity because they feel that this is threatened, the women experience that they have to balance between masculinity and femininity in their working lives. Due to their choice of job they may be said to be facing an interactional dilemma - they are both police officers/electricians (and are therefore expected to appear in 'a masculine way') and women (and are therefore expected to behave in 'a feminine way'). Thus, female police officers and electricians may be said to constantly, both in their working lives and in their private lives, having to negotiate both their gender identity and their professional identity. Thus, the gender strategy for women in the police force and the electricity profession is to balance between femininity and masculinity (Bloksgaard \& Faber 2004, see also Martin 1980, Finstad 2005).

\section{Concluding remarks}

The article shows that the inclusion of a perspective on how women and men are developing their gender identities in relation to work, provides a detailed understanding of the way in which gendering processes are taking place and are contributing to reproducing segregation in the Danish labour market. The article demonstrates that the gendering of work tasks, professions and jobs - i.e. the construction of these as 'masculine' and 'feminine' respectively - is an essential explanation as to why the Danish labour market is still, and to such a great extent, divided into 'men's work' and 'women's work'. That the gendering of a profession is of great importance as to who is seeking employment in that profession, is also confirmed by Liversage (2009). She concludes that one of the main explanations why, over the years, the painting and decorating trade has shifted from a strongly male-dominated to a (almost) mixed gender trade is that the image of this trade has a feminine touch because of its creative element. The identity constructions 
of women and men in relation to conceptions of appropriate work for women and men are thus of great significance when we are seeking to understand what contributes to the reproduction of gender segregation in the Danish labour market. The construction of jobs, professional fields and work in masculine and feminine terms must be seen as an essential reason why there is so little change in the gender structures of the labour market. Gendering is the reason why many women and men do not seek employment in jobs which they perceive as 'jobs appropriate for the opposite sex' - often because they are not even considering it as an option. At the same time, the gendered images of the jobs cause ambivalence and uncertainty in relation to the gender identity of those who are employed unconventionally with regard to their gender.

The gender segregation in the Danish labour market is unfortunate for several reasons: First of all, the gender division in the labour market is contributing to cementing gender stereotypical ideas about female and male qualities and competencies (Bloksgaard \& Faber 2004, Holt et al. 2006). As the article has documented, these ideas may constitute limitations for individual women and men in their orientation towards and choice of work. The reason is that stereotypes define a social categorization characteristic of Western culture, and all men and women are expected to fit into these categories. Those who break with the ideas of 'appropriate' work for women and men, are being met with scepticism and resistance and may be experiencing ambivalence and uncertainty in relation to their own identity and self image. Secondly, the continued gender segregation is also unfortunate seen from a societal perspective. One problem is that the gender division of labour is the most significant reason for unequal pay of women and men in Denmark (Deding \& Larsen 2008, Udsen 2008). Another is that the gender segregation is instrumental in creating bottlenecks in the labour market. In 2011 we are in a situation of economic crisis and increasing unemployment, and especially a number of traditional male professions are experiencing a decline in employment (The Ministry of Employment 2009, Statistics Denmark 2009). At the same time, hospitals and nursing homes find it difficult to recruit staff. However, this situation also holds a potential for change, as previous experience shows that market fluctuations and a decline in 'men's jobs' may help getting more men channelled into 'women's professions' and thereby cause changes in the gendered structures of the labour market (see e.g. Nordjyske Newspaper 2008). In continuation of this, it is, at this moment in time, particularly important to initiate and support initiatives ${ }^{8}$ that go against and seek to break with the established ideas of masculinity, femininity and work thereby trying to expand the space for action of women and men in the labour market.

\section{References}

Acker, Joan (1991): “Hierarchies, Jobs, Bodies: A Theory of Gendered Organizations”. I Judith Lorber \& Susan Farrell (red.): The Social Construction of Gender. London: SAGE Publications.

Alvesson, Mats \& Yvonne Due Billing (1999): Kön och organisation. [Gender and organisation] Lund: Studentlitteratur.

Bloksgaard, Lotte (2009a): Arbejdsliv, forceldreskab og køn - forhandlinger af løn og barsel $i$ tre moderne virksombeder. [Work life, parenthood and gender - negotiations of wage and parental leave in three modern work organizations]. Ph.D thesis, Department of History, International and Social Studies. Aalborg University. 
Bloksgaard, Lotte (2009b): "Mænd i SOSU-faget og kvinder i elfaget". [Men in the social and health care profession and women in the electricity profession]. In LO-dokumentation, No. 4/2009. København: LO, 58-94.

Bloksgaard, Lotte (2009c): SOSU-mond og elektrikerkvinder - hvorfor ikke? En analyse af to kønsdominerede fag. [Male social and health care employees and female electricians why not? A study of two one-gendered professions] Research Report. Aalborg: Specialfunktionen for Ligestilling.

Bloksgaard, Lotte \& Stine Brock Faber (2004): Køn på arbejde. En kvalitativ undersøgelse af mandlige sygeplejerskers og kvindelige politibetientes arbejdsliv. [Gender at Work. A qualitative study of male nurses' and female police officers' working life] Aalborg: Aalborg University Press.

Christensen, Ann-Dorte (2001): “Kønssociologi: Fra kønsroller til kønskonstruktioner" [Gender sociology: From gender roles to gender constructions]. In Michael Hviid Jacobsen et al. (red.) (2001): Tradition og fornyelse - en problemorienteret teoribistorie for sociologien. Aalborg: Aalborg University Press..

Christensen, Ann-Dorte \& Jørgen Elm Larsen (2003): "Mænds ligestilling - om behovet for en differentieret ligestillingsforståelse". [Men's equal rights - the requirement for a differentiated understanding of equality] In Anette Borchorst \& Drude Dahlerup (red.): Ligestillingspolitik som diskurs og praksis. København: Samfundslitteratur.

Connell, Robert W. (1995): Masculinities. Cambridge: Polity Press.

Dahlerup, Drude (1989): “Kan arbejdsmarkedets kønsopdeling brydes?” [Is it possible to break with the gender division in the labour market?] In Drude Dahlerup (red.): Køn sorterer. Kønsopdeling på arbejdspladsen. København: Nordisk Ministerråd.

Deding, Mette \& Mona Larsen (2008): Lønforskelle mellem mond og kvinder 1997-2006. [Wage differences between women and men 1997-2006] København: SFI - Det Nationale Forskningscenter for Velfærd.

Emerek, Ruth \& Helle Holt (2008): “Det kønsopdelte danske arbejdsmarked” [The gender segregated Danish labour market]. In Ruth Emerek \& Helle Holt (red.): Lige muligheder - frie valg? Om det kønsopdelte arbejdsmarked gennem et årti. København: Det nationale Forskningscenter for Velfærd.

Finstad, Liv (2005): "En av gutta? Om kjønn i Politiet". [One of the guys? Gender in the police force] In Marit Egge \& John Strybe (red.): Politirollen gennem 100 år. Oslo: PHS Forskning, 2005: 2.

Gherardi, Silvia (1994): "The gender we think, the gender we do in our everyday organizational lives". In Human Relations", Vol. 47, Iss. 6; pg. 591.

Hirdman, Yvonne (1988): “Gennussystemet - reflexioner kring kvinnors sociala underordning" [The gender order - reflections on the subordination of women]. In Kvinnovetenskaplig Tidskrift, No. 3, 49-63.

Hirdman, Yvonne (1990): “Gennussystemet". [The gender order] I Demokrati och Makt i Sverige. Maktudredningens huvudrapport. Stockholm: SOU, 44, 73-116.

Holt, Helle et al. (2006): Det kønsopdelte arbejdsmarked. [The gender divided labour market] København: Socialforskningsinstituttet.

Kanter, Rosabeth Moss [1977a] (1993): Men and Women of the Corporation. New York: BasicBooks.

Kold, Vibeke (1997): "Det kønne arbejde - faktorer, processer og aktører på det kønsopdelte arbejdsmarked" [the gendered work - determinants, processes and actors in the gender divided labour market]. In Ruth Emerek m.fl. (red.): Brydninger. Perspektiver på det kønsopdelte arbejdsmarked. København: Arbejdsmarkedsstyrelsen.

Krøjer, Jo (2003): “Når farmand kommer hjem - om kønsarbejdsdeling på de socialpædagogiske institutioner". [When daddy comes home - gender division in the social pedagogi- 
cal institutions]. In Katrin Hjort \& Steen Baagøe Nielsen (red.)(2003): Møend og omsorg. København: Hans Reitzels Forlag.

Kvande, Elin (1995): “Forståelser av kjønn og organisasjon”. [Understandings of gender and organisations] In Sosiologisk Tidsskrift, No 4, 285-300.

Liversage, Anika (2009): "Kvinder i malerfaget" [Women in the painting and decorating trade], In LO-dokumentation, No. 4/2009. København: LO, 16-57.

Martin, Susan Erlich (1980): Breaking and Entering. Policewomen on Patrol. Berkeley: University of California Press.

Ministry of Employment (2009): Kvinder og moend på arbejdsmarkedet. [Women and men in the labour market] København: Ministry of Employment.

Nielsen, Steen Baagøe (2003): "Vi trænger til nye kræfter, sagde lederen, og ansatte en mand - om barrierer for mænds omsorg i daginstitutioner". [We need new resources the leader said and hired a man - barriers to men's contributions to care in day care institutions] In Katrin Hjort \& Steen Baagøe Nielsen (red.) (2003): Møend og omsorg. København: Hans Reitzels Forlag.

Nordberg, Marie (2004): "Kvinnlig maskulinitet” och "manlig femininitet”. En möjlighet att överskrida könsdikotomin?”. [Female masculinity and male femininity. An opportunity to transcend the dichotomy of gender? ] In Kvinnovetenskaplig tidskrift, 1-2, 47-64.

Nordjyske Newspaper (2008): Rift om nye SOSU-assistenter. [New social and health care employees in great demand] 08.02.2008.

Simpson, Ruth (2004): Masculinity at work: the experiences of men in female dominated occupations". In Work, employment and society, No. 18, 2, 349-368.

Sjørup, Karen (2006): Moend $i$ kvindefag - en europæeisk undersøgelse i redefinering af moends kønsroller, kønsstereotyper og kønsmoerker. [Men in women's professions] Center for Ligestillingsforskning. Roskilde Universitetscenter.

Statistics Denmark (2009): Kvinder bliver ansat og mænd fyret.[Women are hired and men are fired]

Svare, Helge (2009): Menn i pleie og omsorg - brødre i hvitt. [Men in nursing and caring brothers in white]. Oslo: Universitetsforlaget.

Udsen, Sanne (2008): “Køn og løn - og det kønsopdelte arbejdsmarked”. [Gender and wage and the gender segregated labour market] In Ruth Emerek \& Helle Holt (red.): Lige muligheder - frie valg? Om det kønsopdelte arbejdsmarked gennem et årti. København: SFI.

Warming, Ken (2005): Når mond arbejder i kvindefag - en sociologisk interviewundersøgelse med fokus pà redefinering af arbejdsfunktioner samt maskuliniseringsstrategier inden for fire kønsmoerkede professioner i Danmark. [When men are working in women's jobs] København: CELI - Center for Ligestillingsforskning.

Warming, Kenn (2007): Køn, løn og anerkendelse. En undersøgelse af uligelønnen mellem traditionelle kvinde- og mandefag eksemplificeret ved konkrete sammenligninger af faggrupper med samme loengde uddannelse. [Gender, wage and recognition] København: FOA.

West, Candace \& Don H. Zimmerman (1987): “Doing Gender”. In Gender \& Society, 1, 2, 125-151.

Williams, Christine L. (1991): Gender differences at work. Women and men in non-traditional occupations. London: University of California Press.

Williams, Christine L. (1995): Still a man's world - men who do women's work. London: University of California Press.

\section{End note}

${ }^{1}$ In the article the words gender segregation and gender division of labour are being used to describe the same phenomenon: that women and men work in different job functions and in different sectors, professional fields and jobs. 
${ }^{2}$ Source: the Danish Council of Nurses, figures from 2007.

$34.8 \%$ of the social and health care helpers and $4.9 \%$ of the social and health care assistants. The figures are calculated based on statistics in FLD (Joint municipality office) from December 2008 from the municipalities and regions.

${ }^{4}$ Source: Danish Electricity Confederation 2009, figures from 2008.

${ }_{5}^{5}$ These jobs are all highly gender-dominated and gendered and can therefore be said to constitute especially interesting and meaningful empirical fields with regard to illuminating the meaning of gender in working life. This means that patterns and tendencies which characterise the labour market in general, may appear more transparent and notable here than in more gender complex organizations. Based on an assumption that the male nurses and social and health care employees and the female officers and electricians are to a great extent confronted with the importance of gender in their professional lives, they may be seen as ideal informants about the general dynamics and processes that create and reproduce gender in employment (see also Bloksgaard \& Faber 2004: 12).

${ }^{6}$ At the Social and Health Care School in Northern Jutland. This course was conducted several times during the summer and autumn of 2009.

7 The work tasks in the psychiatry sector are far less likely to be care tasks than in the somatic departments, and physical strength can be an advantage in dealing with patients. The previous education to become a nursing assistant, which provided access to the psychiatry sector, was a masculine gendered education / job function to a far greater extent than nursing (Information from interview with a head nurse in a forensic psychiatric ward Bloksgaard \& Faber 2004).

${ }^{8}$ For recommendations on relevant efforts at breaking down the gender segregation, including attracting and retaining men in social and health care jobs and women in the electricity profession, see Bloksgaard 2009c. 